\title{
Characterization of $\mathrm{P} 2$ receptors for purine and pyrimidine nucleotides in human placental cotyledons
}

\author{
$1, *$ Vera Ralevic, *†Stephen Burrell, $\dagger$ John Kingdom \& *Geoffrey Burnstock
}

Departments of *Anatomy and Developmental Biology, and †Obstetrics/Gyneacology, University College London, Gower Street, London WC1E 6BT

1 The aim of this study was to characterize P2 receptors in the arterial vascular bed of human perfused placental cotyledons. Vasoconstrictor responses to bolus injections of purine and pyrimidine nucleotides were tested at basal tone, and vasodilator responses in preparations with tone raised by perfusion with prostaglandin $\mathrm{F}_{2 \alpha}\left(\mathrm{PGF}_{2 \alpha} ; 10-50 \mathrm{nM}\right)$.

2 At basal tone, bolus injections of the P2X-selective agonist $\alpha, \beta$-methylene ATP $(\alpha, \beta$-meATP; $0.5-$ $500 \mathrm{nmol})$ elicited dose-dependent vasoconstriction. ATP $(0.005-5 \mu \mathrm{mol})$ also elicited dose-dependent vasoconstriction, but was less potent than $\alpha, \beta$-meATP. Vasoconstriction was also elicited by other nucleotides, but only at the highest dose tested $(5 \mu \mathrm{mol})$ : UTP $>$ CTP $=$ ITP $(n=6)$. GTP and TTP did not cause vasoconstriction.

3 Constrictor responses to bolus injections of $\alpha, \beta$-meATP were resistant to desensitization and were not significantly affected when carried out in the presence of $1 \mu \mathrm{M} \alpha, \beta$-meATP added to the perfusate. However, responses to bolus injections of $\alpha, \beta$-meATP were partially blocked by perfusion with $10 \mu \mathrm{M}$ $\alpha, \beta$-meATP. In contrast, responses to ATP and UTP were unaffected by $10 \mu \mathrm{M} \alpha, \beta$-meATP. The P2X receptor antagonist pyridoxalphosphate-6-azophenyl-2',4'-disulphonic acid (PPADS; 10 and $100 \mu \mathrm{M}$ ) had no significant effect on vasoconstriction mediated by $\alpha, \beta$-meATP and ATP.

4 Removal of the endothelium had no significant effect on constrictor responses to $\alpha, \beta$-meATP, ATP and UTP. Inhibition of nitric oxide (NO) synthesis with $\mathrm{N}^{\mathrm{G}}$-nitro-L-arginine methyl ester (L-NAME; $100 \mu \mathrm{M})$ had no significant effect on vasoconstriction to ATP and $\alpha, \beta$-meATP.

5 In preparations with tone raised with $\mathrm{PGF}_{2 \alpha}(10-50 \mathrm{nM})$ vasodilatation was elicited by nucleotides with the following order of potency: $2 \mathrm{MeSATP}=\mathrm{ADP}>>$ ATP $>$ UTP $>$ CTP $=\mathrm{GTP}=\mathrm{ITP}=\mathrm{TTP}$. $\mathrm{pD}_{2}$ values were: $2 \mathrm{MeSATP}, 10.03 \pm 0.26(n=7)$; ADP, $9.97 \pm 0.40(n=5)$; ATP, $8.89 \pm 0.18(n=7)$; UTP, $7.79 \pm 0.35(n=7)$. Maximal responses to 2MeSATP and ADP were similar and were approximately $40 \%$ greater than maximal responses to ATP and UTP.

6 Vasodilator responses to nucleotides were abolished by L-NAME (100 $\mu \mathrm{M})$ and by removal of the endothelium.

7 In conclusion, contractile responses mediated by $\alpha, \beta$-meATP and ATP in human placental smooth muscle are resistant to desensitization and insensitive to PPADS and, thus, show a dissimilar pharmacological profile to the classic smooth muscle $\mathrm{P} 2 \mathrm{X}_{1}$ receptor. There may be two subtypes of smooth muscle P2 receptor based on differential antagonism of $\alpha, \beta$-meATP and ATP with $\alpha, \beta$-meATP. A smooth muscle P2 receptor mediates vasoconstriction to UTP, and may indicate a further subtype. Endothelium-dependent, NO-dependent, vasodilatation to 2MeSATP and ADP may be mediated by $\mathrm{P}_{2} \mathrm{Y}_{1}$ receptors, while endothelial $\mathrm{P} 2 \mathrm{Y}_{2}$ receptors are likely to mediate NO-dependent relaxation to ATP and UTP.

Keywords: Endothelium; perfusion; placenta; P2-receptors; pyrimidine receptors; PPADS

\section{Introduction}

Purine and pyrimidine nucleotides elicit diverse biological effects via distinct cell-surface P2 receptors (see Olsson \& Pearson, 1990; Ralevic \& Burnstock, 1991; Dubyak \& ElMoatassim, 1993). These receptors have been divided into two broad groups: $\mathrm{P} 2 \mathrm{X}$ receptors, which are intrinsic ion channels, and $\mathrm{P} 2 \mathrm{Y}$ receptors, which are $\mathrm{G}$ protein-coupled receptors (Abbracchio \& Burnstock, 1994; Fredholm et al., 1994). These families have been further subdivided according to the distinct structure of mammalian receptors. The $\mathrm{P} 2 \mathrm{X}$ receptor family comprises subtypes $\mathrm{P} 2 \mathrm{X}_{1-6}$. From the vascular perspective $\mathrm{P} 2 \mathrm{X}_{1}$ (previously known as $\mathrm{P}_{2 \mathrm{X}}$ ) is the most relevant, being found in smooth muscle. The P2Y family includes the receptors $\mathrm{P} 2 \mathrm{Y}_{1}$ and $\mathrm{P} 2 \mathrm{Y}_{2}$ (formerly known as $\mathrm{P}_{2 \mathrm{Y}}$ and $\mathrm{P}_{2 \mathrm{U}}$ respectively), the $\mathrm{P}_{2 \mathrm{~T}}$ receptor (which has not yet been cloned), and a further five cloned subtypes ( $\left.\mathrm{P} 2 \mathrm{Y}_{3-7}\right)$.

Pharmacological characterization of purine receptors relies on agonist selectivities and potency orders as there is a

\footnotetext{
${ }^{1}$ Author for correspondence.
}

lack of selective antagonists at purine and uridine nucleotide-specific receptors. The stable analogue of adenosine $5^{\prime}$ triphosphate (ATP), $\alpha, \beta$-methylene ATP $(\alpha, \beta$-meATP), is a potent agonist and desensitizing agent at the smooth muscle P2X 1 receptor (Burnstock \& Kennedy, 1985). Rapid desensitization is characteristic of $\mathrm{P} 2 \mathrm{X}_{1}$ and $\mathrm{P} 2 \mathrm{X}_{3}$ receptors, whereas all other subtypes of $\mathrm{P} 2 \mathrm{X}$ receptor are resistant to desensitization (Evans \& Surprenant, 1996). Pyridoxalphosphate-6-azophenyl-2', 4'-disulphonic acid (PPADS) is a selective antagonist at smooth muscle $\mathrm{P} 2 \mathrm{X}_{1}$-receptors in rabbit and rat blood vessels (Windscheif et al., 1994; Ziganshin et al., 1994), but can also block $\mathrm{P}_{2} \mathrm{Y}_{1}$ responses (Ralevic \& Burnstock, 1996). 2-MethylthioATP (2MeSATP) is a potent agonist at vascular $\mathrm{P} 2 \mathrm{Y}_{1}$ receptors and is selective for these versus $\mathrm{P} 2 \mathrm{Y}_{2}$ receptors. However, it is also active at $\mathrm{P} 2 \mathrm{X}_{1}$ receptors. The $\mathrm{P} 2 \mathrm{Y}_{2}$ receptor is characterized by the equipotency of ATP and uridine 5'-triphosphate (UTP). In addition to its effects on $\mathrm{P}_{2} \mathrm{Y}_{2}$ receptors UTP also acts on uridine nucleotide-specific receptors or pyrimidinoceptors, which are not activated by purines (von Kugelgen et al., 1987; Saiag et al., 1990; 1992; Ralevic \& Burnstock, 1991), 
and which may be equivalent to $\mathrm{P}_{2} \mathrm{Y}_{4}$ and/or $\mathrm{P} 2 \mathrm{Y}_{6}$ receptors (Chang et al., 1995; Communi et al., 1996a,b).

This study characterizes the $\mathrm{P} 2$ receptors mediating responses to purine and pyrimidine nucleotides in the arterial bed of human placental cotyledons. Read and colleagues (1993) described P2X and P2Y receptors in human placental cotyledons, but did not examine the effects of pyrimidines. $\mathrm{P} 2 \mathrm{Y}_{2}$ receptors have been described in human trophoblastic cells where they were shown to mediate an increase in intracellular $\mathrm{Ca}^{2+}$ (Petit \& Bélisle, 1995). A G protein-coupled P2 receptor, $\mathrm{P} 2 \mathrm{Y}_{1}$, has been cloned from human placenta, although its agonist activity profile was not determined (Leon et al., 1995). $\mathrm{P}_{2} \mathrm{Y}_{4}$, cloned from human genomic DNA and showing strong expression in placenta, was activated by UT$\mathrm{P}=\mathrm{UDP}>\mathrm{ATP}=\mathrm{ADP}$ (Communi et al., 1996a,b). A preliminary account of our results has been presented at the Purines 1996 Meeting (Ralevic et al., 1996).

\section{Methods}

Tissue source

Placentae were obtained from 16 healthy women (20-43 years) undergoing elective Caesarean section with epidural anaesthesia. None of the women had received any drug treatment known to have chronic vascular effects. Two or three placental cotyledons were isolated from each placenta. For each cotyledon the third or fourth chorionic plate branch of the umbilical artery was cannulated, the corresponding vein for outflow was severed and the cotyledon was flushed with $2 \mathrm{ml}$ of heparine treated saline $\left(10 \mathrm{iu} \mathrm{ml}{ }^{-1}\right)$. Cotyledons were cut away from the surrounding tissue and removed for perfusion.

\section{Perfusion of placental cotyledons}

Preparations were placed in a humid chamber (custom made at University College London) and perfused at a constant flow

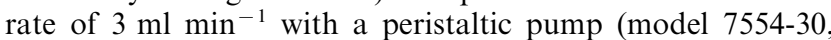
Cole-Parmer Instrument Co., Chicago, Illinois). The perfusate was Krebs solution ( $\mathrm{pH}$ 7.4) of the following composition (mM): $\mathrm{NaCl} 133, \mathrm{KCl} 4.7, \mathrm{NaH}_{2} \mathrm{PO}_{4}$ 1.35, $\mathrm{NaHCO}_{3}$ 16.3, $\mathrm{MgSO}_{4} 0.61, \mathrm{CaCl}_{2} 2.52$ and glucose 7.8 , with bovine serum albumin $\left(20 \mathrm{~g} \mathrm{1}^{-1}\right)$, gassed with $95 \% \mathrm{O}_{2}-5 \% \mathrm{CO}_{2}$ and maintained at $37^{\circ} \mathrm{C}$. Responses were measured as changes in perfusion pressure $(\mathrm{mmHg})$ with a pressure transducer (model P23XL, Viggo-Spectramed, Oxnard, CA) on a side arm of the perfusion cannula, and recorded on a polygraph (model 7D, Grass Instrument Co., Quincy, Mass).

\section{Experimental protocol}

Preparations were allowed to equilibrate for $20 \mathrm{~min}$ before experimentation. Preparations not achieving a stable perfusion pressure of less than $50 \mathrm{mmHg}$ were discarded. At basal tone responses of the cotyledons were tested to doses of guanosine $5^{\prime}$-triphosphate (GTP), cytidine $5^{\prime}$-triphosphate (CTP), inosine $5^{\prime}$-triphosphate (ITP), UTP, ATP and $\alpha, \beta$ meATP. Response curves were reproducible and were repeated in the same preparations $30 \mathrm{~min}$ after one of the following treatments: (a) endothelium removal (see below), (b) addition of PPADS $(10$ and $100 \mu \mathrm{M})$ to the perfusate, (c) addition of $\alpha, \beta$-meATP (10 and $100 \mu \mathrm{M})$ to the perfusate. In separate preparations tone was raised with prostaglandin $\mathrm{F}_{2 \alpha}$ $\left(\mathrm{PGF}_{2 \alpha} ; 10-50 \mathrm{nM}\right)$ by approximately $100 \mathrm{mmHg}$ above baseline, and dose-response curves to purine and pyrimidine nucleotides were constructed. Nucleotides were reapplied after endothelium removal or $30 \mathrm{~min}$ after addition of $\mathrm{N}^{\mathrm{G}}$ nitro-L-arginine methyl ester (L-NAME, $100 \mu \mathrm{M}$ ) to the perfusate. Doses of purine or pyrimidine compounds were applied as $50 \mu$ l bolus injections via a rubber septum proximal to the preparation.

\section{Endothelium removal}

The endothelium was removed by perfusion of the cotyledons with $2 \mathrm{ml}$ of a solution of sodium deoxycholate $\left(2 \mathrm{mg} \mathrm{ml}^{-1}\right.$ in saline) via the injection port, as described for the rat perfused mesenteric arterial bed (Ralevic \& Burnstock, 1988).

\section{Drugs used}

The following drugs were obtained from Sigma: ATP (disodium salt), UTP (sodium salt), CTP, GTP, ITP, thymidine 5'triphosphate (TTP), $\alpha, \beta$-methylene ATP (lithium salt), adenosine 5'-diphosphate (ADP; sodium salt), sodium nitroprusside (SNP). 2-MethylthioATP (tetrasodium salt) was from Research Biochemicals Inc. PPADS was a generous gift from Dr G. Lambrecht (University of Frankfurt, Germany) and from Tocris Cookson (Bristol, UK.).

\section{Data analyses}

Vasodilator responses were measured as changes in perfusion pressure $(\mathrm{mmHg})$ and evaluated as a percentage of the $\mathrm{PGF}_{2 \alpha^{-}}$ induced increase in tone above baseline. Results are presented as mean \pm s.e.mean. $\mathrm{pD}_{2}$ is defined as the negative $\log$ of the dose of agonist required to produce $50 \%$ of the maximal response. Where dose-response curves did not reach a maximum these were compared by analysis of variance with repeated measures, with post hoc analysis by Student's $t$ test. Differences between means were determined by Student's $t$ test and were considered significant when $P<0.05$.

\section{Results}

\section{Baseline characteristics}

Basal perfusion pressure of the placental cotyledons was $32.4 \pm 3.1 \mathrm{mmHg}(n=36)$.

\section{Effects of purine and pyrimidine nucleotides at basal tone}

At basal tone, $\alpha, \beta$-meATP $(0.5-500 \mathrm{nmol})$ and ATP $(0.005-$ $5 \mu \mathrm{mol})$ elicited dose-dependent vasoconstriction of the placental cotyledons, with $\alpha, \beta$-meATP being the most potent constrictor $(n=14)$ (Figure 1). Responses to $\alpha, \beta$-meATP and ATP were slow to reach a maximum (approximately 30-60 s) and were long-lasting, particularly at high doses, taking up to $10 \mathrm{~min}$ to return to baseline. The following nucleotides elicited vasoconstriction only at the highest dose tested $(5 \mu \mathrm{mol})$ : UTP $>\mathrm{CTP}=\mathrm{ITP}(n=6-8)$. GTP and TTP did not cause vasoconstriction $(n=4)$. Dose-response curves to the nucleotides were reproducible within the same preparation.

\section{Effect of $\alpha, \beta$-meATP on vasoconstrictor responses to nucleotides}

Addition of $1 \mu \mathrm{M} \alpha, \beta$-meATP produced an increase in basal perfusion pressure of $8.0 \pm 4.1 \mathrm{mmHg}(n=4)$ which was maintained in the presence of $\alpha, \beta$-meATP. Responses to doses of $\alpha, \beta$-meATP were not significantly affected by $\alpha, \beta$-meATP $(1 \mu \mathrm{M})$ added to the perfusate (Figure $2 \mathrm{a}) . \alpha, \beta$-meATP at $10 \mu \mathrm{M}$ produced an increase in basal perfusion pressure of $11.6 \pm 4.5 \mathrm{mmHg}(n=5)$ which was maintained, and did not return to baseline. At $10 \mu \mathrm{M} \alpha, \beta$-meATP responses to the lowest doses of $\alpha, \beta$-meATP were abolished (Figure $2 \mathrm{a}$ ). In contrast, responses to ATP (Figure 2b) and UTP were unaffected by $\alpha, \beta$-meATP $(1$ and $10 \mu \mathrm{M})$.

\section{Effect of PPADS on vasoconstrictor responses to nucleotides}

PPADS $(100 \mu \mathrm{M})$ did not have any significant effect on the basal tone of the preparations. Vasoconstrictor responses to 


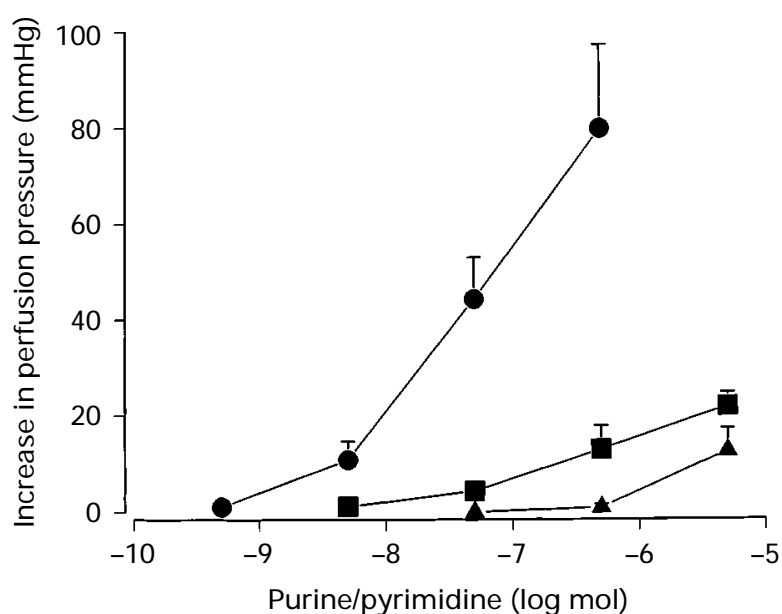

Figure 1 Dose-response curves to $\alpha, \beta$-meATP $(\boldsymbol{O},=14)$, ATP $(\mathbf{\square},=14)$ and $\operatorname{UTP}(\boldsymbol{\Lambda},=12)$ in the arterial bed of human placenta. Vertical lines show s.e.mean.
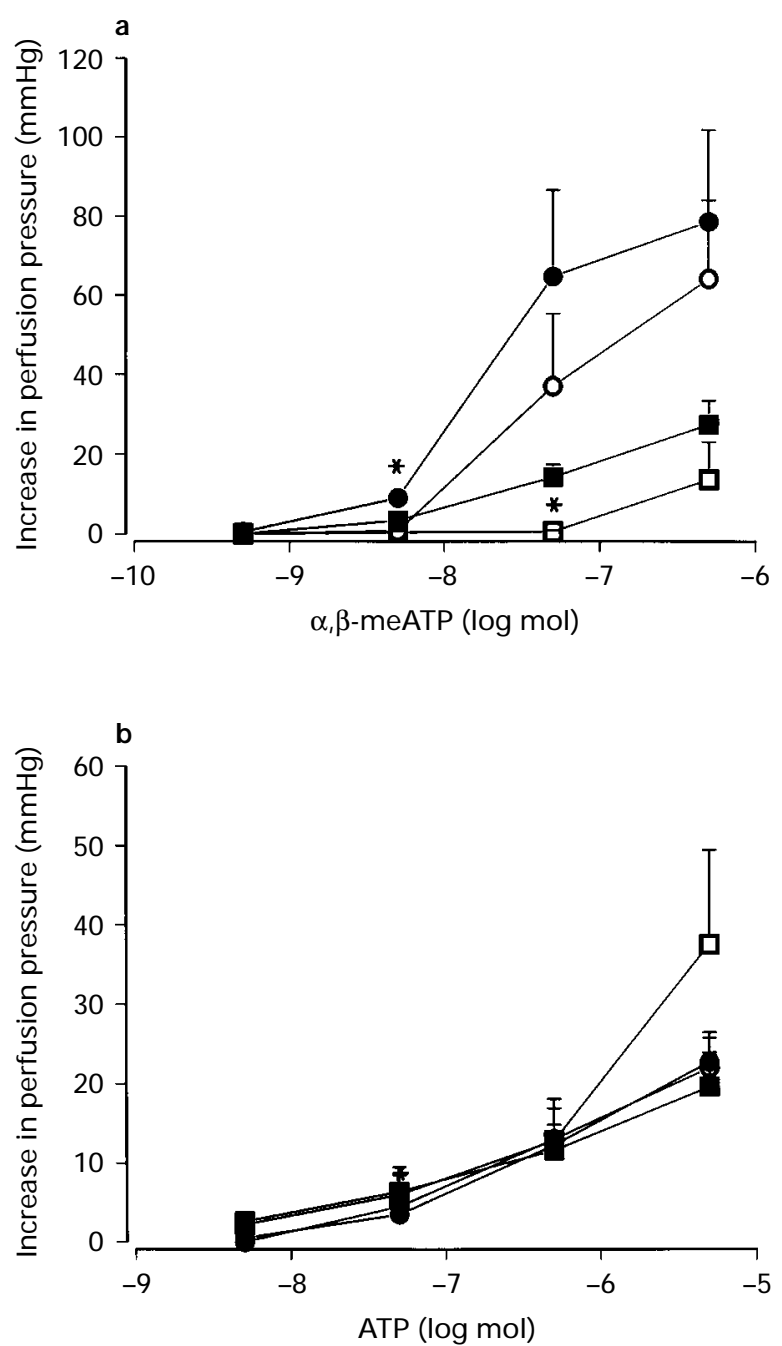

Figure 2 Effect of $\alpha, \beta$-meATP ( 1 and $10 \mu \mathrm{M}$ ) on responses to (a) $\alpha, \beta$-meATP, (b) ATP. (a) Dose-response curves to $\alpha, \beta$-meATP in the absence (O) and presence $(\bigcirc)$ of $1 \mu \mathrm{M} \alpha, \beta$-meATP $(n=4)$, and in the absence ( $\square$ ) and presence $(\square)$ of $10 \mu \mathrm{M} \alpha, \beta$-meATP $(n=5)$. * Denotes significant difference between responses in controls and in the presence of $10 \mu \mathrm{M} \alpha, \beta$-meATP $(P<0.05)$. (b) Dose-response curves to ATP in the absence (O) and presence $(\bigcirc)$ of $1 \mu \mathrm{M} \alpha, \beta$-meATP $(n=4)$, and in the absence $(\square)$ and presence $(\square)$ of $10 \mu \mathrm{M} \alpha, \beta$ meATP $(n=5)$. Reproducibility of responses allowed response curves in the absence and presence of $\alpha, \beta$-meATP to be generated consecutively in the same preparations. Vertical lines show s.e.mean.
UTP, ATP and $\alpha, \beta$-meATP were not significantly affected by PPADS (10 and $100 \mu \mathrm{M})(n=4-6)$ (data not illustrated).

\section{Effect of endothelium removal and $L-N A M E$ on} vasoconstrictor responses to nucleotides

The NO synthase inhibitor L-NAME $(100 \mu \mathrm{M})$ increased basal tone by $9.0 \pm 3.7 \mathrm{mmHg}$ in four out of five preparations. Responses to $\alpha, \beta$-meATP, ATP and UTP in the presence of LNAME were not significantly different from controls (Figure $3 a)$. Removal of the endothelium produced a significant increase in basal tone of the preparations of $14.4 \pm 4.6 \mathrm{mmHg}$ $(n=5)$. Removal of the endothelium did not significantly affect responses to $\alpha, \beta$-meATP and ATP, although there appeared to be a trend towards augmentation (Figure $3 b$ ).

\section{Effects of purine and pyrimidine nucleotides at raised tone}

Addition of $\mathrm{PGF}_{2 \alpha}(32 \pm \mathrm{nM})$ raised the tone of the preparations by $87.5 \pm 11.1 \mathrm{mmHg}(n=10)$ above baseline. Dose-dependent vasodilatation was elicited by nucleotides with the following order of potency: 2MeSATP $=$ ADP $>>$ ATP $>$ $\mathrm{UTP}>\mathrm{CTP}=\mathrm{GTP}=\mathrm{ITP}=\mathrm{TTP}(n=5)($ Figure 4$)$. Maximal
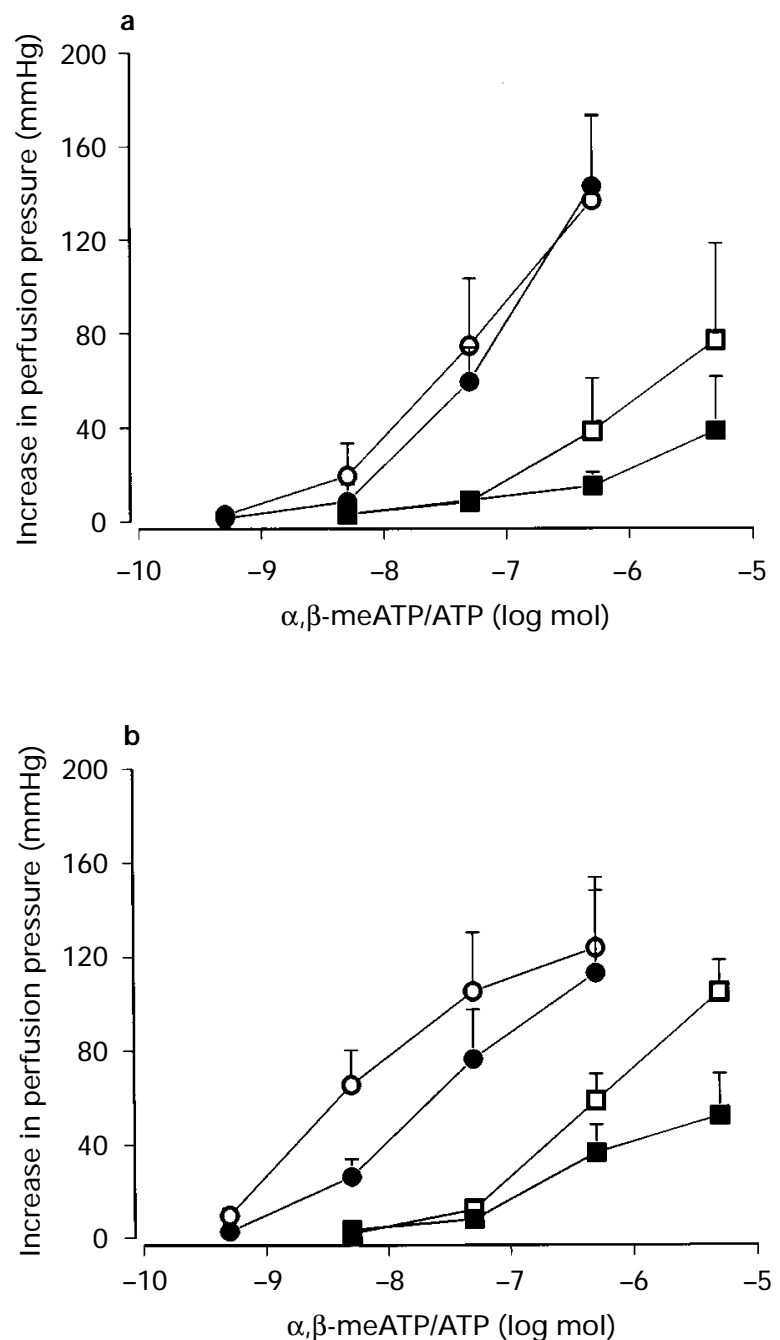

Figure 3 (a) Responses to $\alpha, \beta$-meATP (circles, $n=5$ ) and ATP (squares, $n=5$ ) in the absence (solid symbols) and presence (open symbols) of $\mathrm{N}^{\mathrm{G}}$-nitro-L-arginine methyl ester (L-NAME; $\left.100 \mu \mathrm{M}\right)$. There was no significant difference between the mean responses. (b) Responses to $\alpha, \beta$-meATP (circles, $n=5$ ) and ATP (squares, $n=5$ ) in the presence (solid symbols) and absence (open symbols) of endothelium. There was no significant difference between the mean responses. Vertical lines show s.e.mean. 
relaxations were not significantly different between 2MeSATP, $55.75 \pm 5.71(n=7)$ and ADP, $46.76 \pm 9.00(n=5)$, or between ATP, $31.74 \pm 6.56(n=7)$ and UTP $30.38 \pm 4.06(n=7) . \mathrm{pD}_{2}$ values for $2 \mathrm{MeSATP}$ and ADP were not significantly different, being $10.03 \pm 0.26(n=7)$ and $9.97 \pm 0.40(n=5)$, respectively. The $\mathrm{pD}_{2}$ value for ATP, $8.89 \pm 0.18(n=7)$, was significantly greater than that for UTP, $8.05 \pm 0.28(n=7)(P<0.05)$.

\section{Effect of endothelium removal and $L-N A M E$ on vasodilator responses to nucleotides}

Vasodilator responses to purine and pyrimidine nucleotides were abolished following removal of the endothelium with sodium deoxycholate ( $n=3$; Figure 5 ). Vasodilator responses to nucleotides were also abolished by L-NAME $(100 \mu \mathrm{M}$; $n=4$ ) (Figure 6). After each of these treatments the ability of the smooth muscle to relax was unimpaired, as evidenced by responses to the direct smooth muscle relaxing agent SNP $(0.005-50 \mathrm{nmol}$ ), which were augmented (Figures 5 and 6$)$.

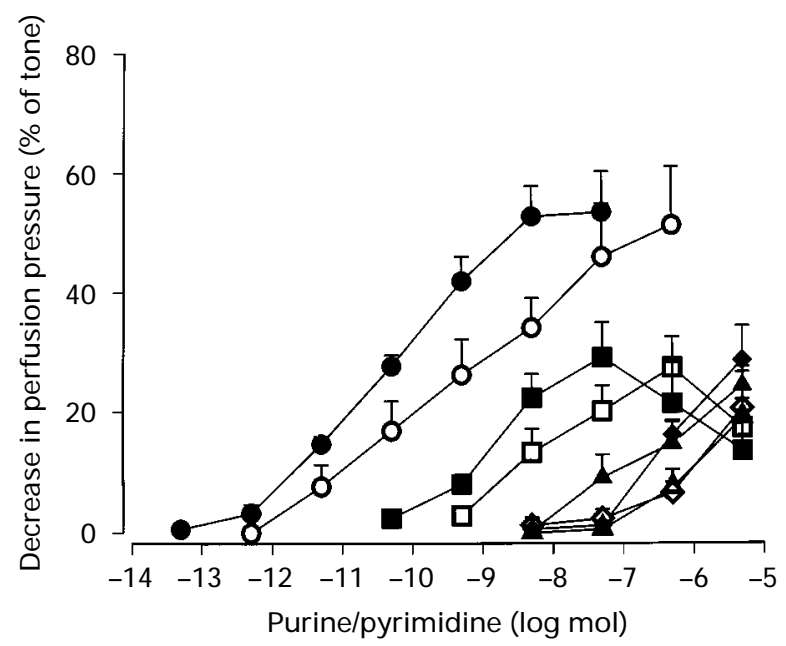

Figure 4 Vasodilator dose-response curves to purine and pyrimidine nucleotides in human placental cotyledons with tone raised by $\mathrm{PGF}_{2 \alpha}(10-50 \mathrm{nM})$. (๑) $2 \mathrm{MeSATP}(n=7) ;(\bigcirc)$ ADP $(n=5)$; $(\square)$ ATP $(n=7) ;(\square)$ UTP $(n=7) ;(\bullet) \operatorname{GTP}(n=5) ;(\boldsymbol{\Delta})$ ITP $(=5) ;(\diamond) \operatorname{CTP}(n=6) ;(\triangle)$ TTP $(n=5)$. Vertical lines show s.e.mean.

\section{Discussion}

Several factors currently contribute to obscure the conclusions which can be drawn from pharmacological approaches to $\mathrm{P}_{2}$ purine receptor characterization. These include: a lack of subtype-selective $\mathrm{P} 2$ receptor agonists and antagonists, the fact that most commercially available nucleotides are not pure and the fact that most nucleotides are extensively modified by interconversion or degradation into products with widely different pharmacological activities (including lack of activity). Further complications are introduced when bolus injections are used because of spatio-temporal gradients of nucleotides. These considerations must be taken into account when drawing conclusions based on rank orders of agonist potencies, which still play an important role in the characterization of $\mathrm{P} 2$ receptors. The division of $\mathrm{P} 2 \mathrm{X}$ receptors into desensitizing and non-desensitizing phenotypes, a property which is independent of the above-mentioned problems, presents an invaluable handle on $\mathrm{P} 2 \mathrm{X}$ receptor characterization.

The present study confirms and extends previous findings regarding characterization of $\mathrm{P} 2$ receptors in the human placental vasculature. Dose-dependent vasoconstriction to $\alpha, \beta$ meATP indicates that $\mathrm{P} 2 \mathrm{X}$ receptors are present in the arterial vasculature of the human placental circulation, consistent with the findings of Read and coworkers (1993). A major novel finding is that responses to both $\alpha, \beta$-meATP and ATP were resistant to desensitization, as indicated by the reproducibility of the responses and the fact that contractions produced during continuous perfusion with $\alpha, \beta$-meATP were sustained. This was unexpected since rapid desensitization is a characteristic of vascular smooth muscle $\mathrm{P}_{2} \mathrm{X}_{1}$ receptors (Burnstock \& Kennedy, 1985). In addition, responses to bolus injection of $\alpha, \beta$ meATP were not blocked by continuous perfusion with $1 \mu \mathrm{M}$ $\alpha, \beta$-meATP. Lack of desensitization of responses to $\alpha, \beta$ meATP has also been shown in human placental chorionic surface arteries (Dobronyi et al., 1997).

Block of responses to bolus injections of $\alpha, \beta$-meATP, but not to ATP, by perfusion with a relatively high concentration $(10 \mu \mathrm{M})$ of $\alpha, \beta$-meATP suggests that there may be at least two different subtypes of smooth muscle $\mathrm{P} 2$ receptor in human placenta. The partial block of responses to bolus injections of $\alpha, \beta$-meATP during continuous perfusion with $10 \mu \mathrm{M} \alpha, \beta$ meATP may be due to competition for $\mathrm{P} 2 \mathrm{X}$ receptors rather than desensitization. The greater potency of $\alpha, \beta$-meATP compared to ATP may be due at least in part to its greater resistance to degradation by ectonucleotidases (Crack et al., 1994).

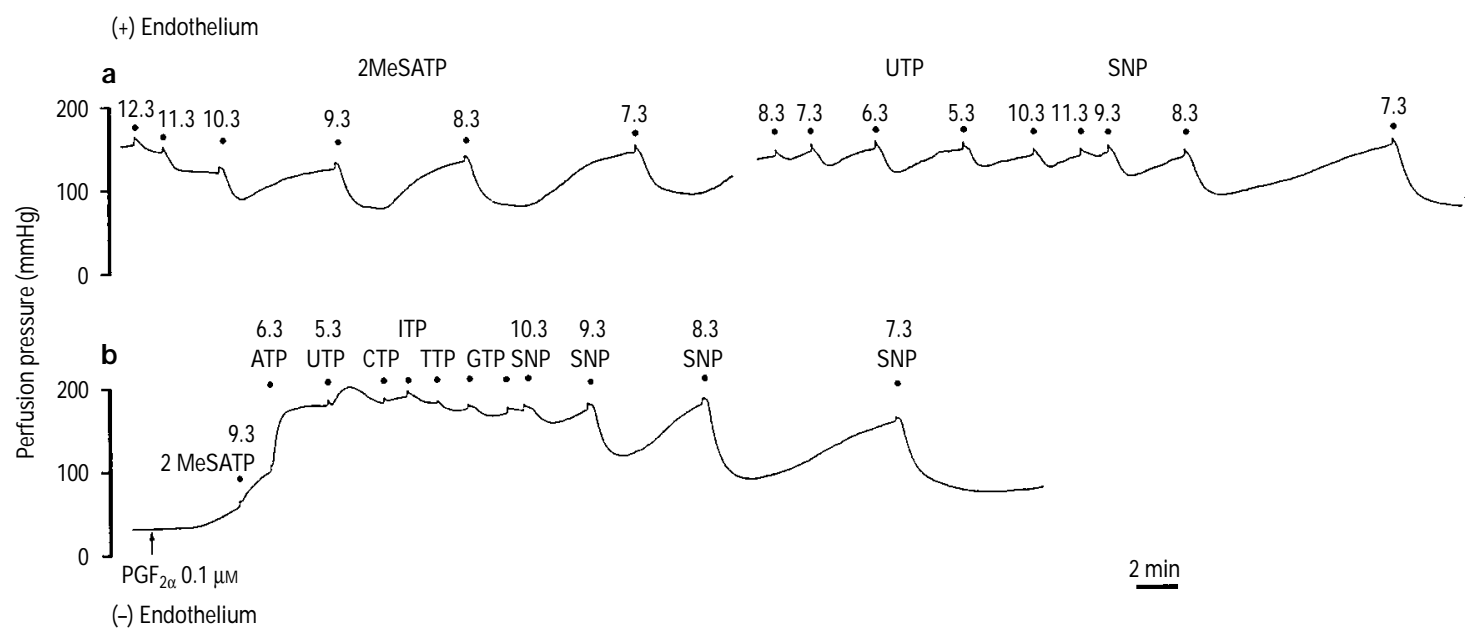

Figure 5 Representative trace showing vasodilator responses (decrease in perfusion pressure, $\mathrm{mmHg}$ ) of a single human placental cotyledon to purine and pyrimidine nucleotides and to sodium nitroprusside (SNP; 10.3 - 7.3) before (a) and after (b) removal of the endothelium. Doses are given as $-\log$ mol. In (b), UTP, CTP, ITP and TTP were all applied as doses of 5.3 ( - log mol; equivalent to $5 \mu \mathrm{mol})$. GTP was applied at 6.3 and $5.3(-\log \mathrm{mol})$. Tone of the preparations was raised with $20 \mathrm{nM}^{\mathrm{PGF}} 2 \alpha$ in the presence of endothelium (not shown; basal perfusion pressure $27 \mathrm{mmHg}$ ) and $100 \mathrm{nM}^{\mathrm{PGF}_{2 \alpha}}$ in the absence of endothelium (basal perfusion pressure $34 \mathrm{mmHg}$ ). 
Control

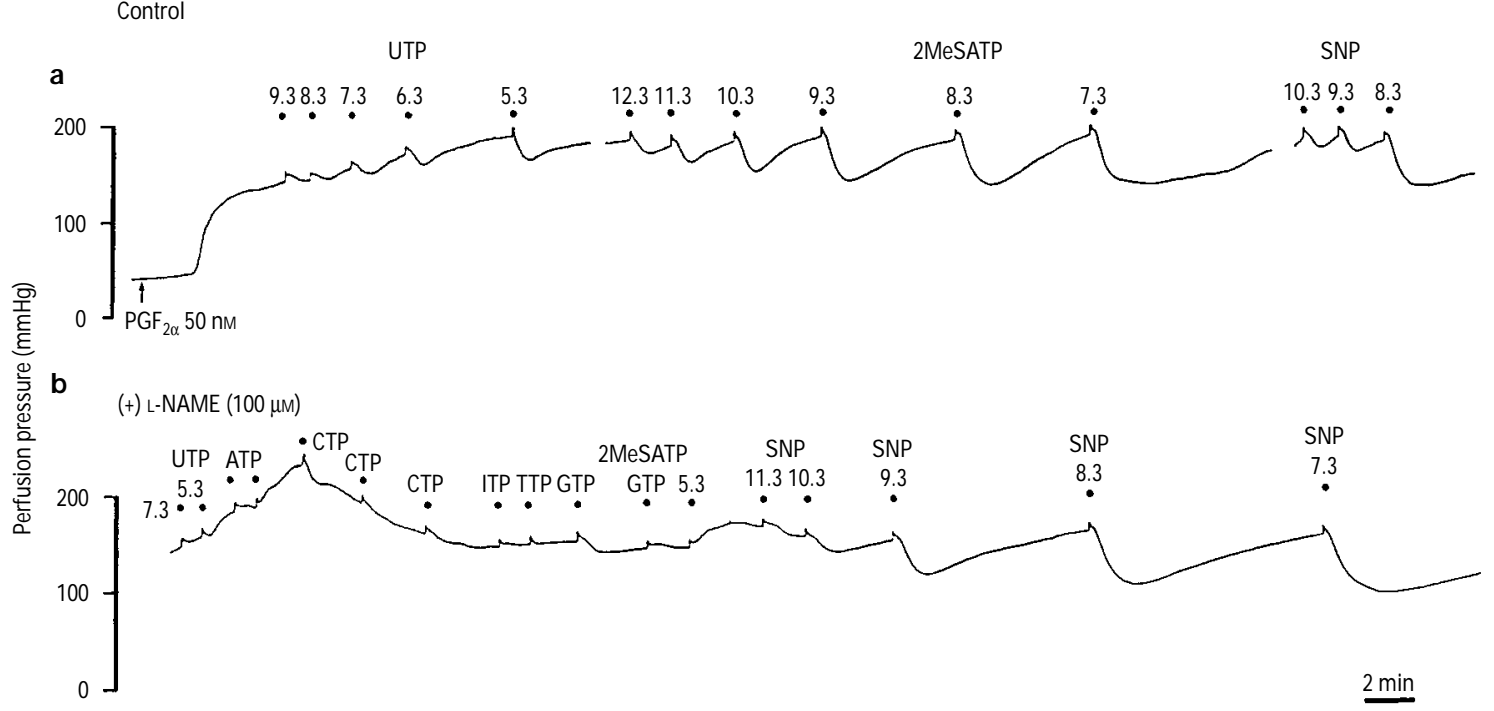

Figure 6 Representative trace showing vasodilator responses (decrease in perfusion pressure, $\mathrm{mmHg}$ ) of a single human placental cotyledon to purine and pyrimidine nucleotides and to sodium nitroprusside (SNP) in the absence (a) and presence (b) of $\mathrm{N}^{\mathrm{G}}$-nitroL-arginine methyl ester (L-NAME; $100 \mu \mathrm{M})$. Doses are given as $-\log$ mol. In (b), UTP, ITP and TTP were all applied as doses of $5.3(-\log \mathrm{mol}$; equivalent to $5 \mu \mathrm{mol})$. ATP was applied at doses of 6.3 and 5.3; CTP at 7.3, 6.3 and 5.3; GTP at 6.3 and 5.3. Tone of the preparations was raised with $50 \mathrm{nM} \mathrm{PGF}_{2 \alpha}$ in the absence of L-NAME (basal perfusion pressure $42 \mathrm{mmHg}$ ) and $30 \mathrm{nM}$ PGF $2 \alpha$ in the presence of L-NAME (tone did not return fully to baseline during washout).

Contractile responses to UTP as well as ATP were unaffected by $\alpha, \beta$-meATP $(10 \mu \mathrm{M})$, raising the possibility that these nucleotides act at a common receptor. However, it is also possible that ATP and UTP act at distinct receptors, with uridine nucleotide-specific receptors mediating the responses to UTP (von Kügelgen et al., 1987; Saiag et al., 1990, 1992; Ralevic \& Burnstock, 1991). Differentiation between these two possibilities requires the discovery of selective antagonists.

The failure of PPADS at $100 \mu \mathrm{M}$ (a concentration 100 fold greater than that obtained for its $\mathrm{IC}_{50}$ value at $\mathrm{P} 2 \mathrm{X}$ receptors in other tissues) to block responses to $\alpha, \beta$-meATP and ATP is not consistent with the expected pharmacological profile of $\mathrm{P} 2 \mathrm{X}_{1}$ receptors, the only $\mathrm{P} 2 \mathrm{X}$ subtype shown to date to be expressed in smooth muscle. Insensitivity to PPADS has been described for $\mathrm{P}_{2} \mathrm{X}_{4}$ and $\mathrm{P}_{2} \mathrm{X}_{6}$ receptors; all the other subtypes are antagonized by PPADS (Buell et al., 1996; Collo et al., 1996). Resistance to desensitization is characteristic of $\mathrm{P} 2 \mathrm{X}_{2}, \mathrm{P} 2 \mathrm{X}_{4}$, $\mathrm{P} 2 \mathrm{X}_{5}$ and $\mathrm{P} 2 \mathrm{X}_{6}$ receptors and the heteropolymer $\mathrm{P} 2 \mathrm{X}_{2} / \mathrm{P} 2 \mathrm{X}_{3}$ (Collo et al., 1996; Evans \& Surprenant, 1996; North, 1996; Garcia-Guzman et al., 1997). Apparently more rapid desensitization of the human $\mathrm{P}_{2} \mathrm{X}_{4}$ receptor (Garcia-Guzman et al., 1997) compared to the rat $\mathrm{P} 2 \mathrm{X}_{4}$ receptor (Buell et al., 1996) suggests that there may be species differences within $\mathrm{P} 2 \mathrm{X}$ receptor subtypes which may also be the case with the other P2X receptors. With the exception of $\mathrm{P} 2 \mathrm{X}_{2} / \mathrm{P} 2 \mathrm{X}_{3}$, these receptors are relatively insensitive to $\alpha, \beta$-meATP. Thus, placental smooth muscle $\mathrm{P}_{2}$ receptors are dissimilar to all of the above recombinant receptors and it may be that heteropolymerization accounts for the atypical pharmacological profile.

Removal of the endothelium did not impair constrictor responses to UTP, ATP and $\alpha, \beta$-meATP, indicating that the $\mathrm{P}_{2}$ receptors are present on the vascular smooth muscle. L-NAME and endothelium removal significantly increased the tone of the preparations, suggesting basal release of NO from the endothelium. L-NAME did not significantly affect responses to ATP and $\alpha, \beta$-meATP, suggesting that NO does not modulate contractile responses of human placental cotyledons under the conditions of the present study.

At raised tone, responses to the nucleotides were abolished following removal of the endothelium and were blocked by LNAME, indicating that vasodilation is mediated by endothelial NO. Responses to the NO donor SNP have been found to be augmented after these treatments in other preparations (Shirasaki \& Su, 1985; Ralevic et al., 1991).
In the present study, vasodilator responses to 2MeSATP and ADP were similar both in their maximum effect and potency, whereas responses to ATP were less potent and efficacious, differing from the typical agonist profile of vascular $\mathrm{P}_{2} \mathrm{Y}_{1}$ receptors $(2 \mathrm{MeSATP}>\mathrm{ATP}>\mathrm{ADP})$. Responses to UTP were similar to those of ATP, consistent with the presence of a distinct receptor, possibly a $\mathrm{P} 2 \mathrm{Y}_{2}$ receptor. An ADP-specific $\mathrm{P} 2 \mathrm{Y}$ receptor (activated by 2MeSATP but weakly or not at all by ATP) coexisting with the $\mathrm{P} 2 \mathrm{Y}_{2}$ receptor has also been described in osteoblastic cells (Reimer \& Dixon, 1992), hepatocytes (Dixon et al., 1995), rat brain microvascular endothelial cells (Frelin et al., 1993; Feolde et al., 1995; Webb et al., 1996) and on the endothelium of the rat mesenteric arterial bed (Ralevic \& Burnstock, 1996). Molecular evidence suggests that this is a $\mathrm{P}_{2} \mathrm{Y}_{1}$ receptor rather than a further $\mathrm{P} 2 \mathrm{Y}$ receptor subtype (Webb et al., 1996).

$\mathrm{P}_{2} \mathrm{Y}_{4}$, a receptor strongly expressed in human placenta (Communi et al., 1996) had a different agonist profile to the receptors characterized in the present study. It is possible that the placental $\mathrm{P} 2 \mathrm{Y}_{4}$ receptor is not a vascular receptor.

The suggestion of distinct receptors for ADP and ATP/UTP may be significant with respect to the physiological sources of these nucleotides. The placental vasculature is not innervated, excluding the possibility that ATP is released as a cotransmitter from perivascular nerves. Thus, the role of endothelial cells, trophoblasts, platelets and other formed elements of blood as sources of these nucleotides assumes greater significance. Vasomotor control of foetoplacental blood flow is of particular clinical interest since impaired umbilical artery perfusion is associated with a high risk of perinatal death (Alfirevic \& Neilson, 1995). Delineating the role of purines in this vascular bed may lead to possible therapeutic methods of improving placental blood flow.

Despite the obstacles briefly discussed above we want to draw several tentative conclusions from the present study. There are at least two types of $\mathrm{P} 2$ receptors on the vascular smooth muscle of human term placenta, neither of which is similar to the classic smooth muscle $\mathrm{P} 2 \mathrm{X}_{1}$ receptor, based on resistance to desensitization and insensitivity to PPADS. One of these is a P2X receptor which mediates vasoconstriction to $\alpha, \beta$-meATP, and the other a distinct P2 receptor which mediates constriction to ATP. There may be a third subtype which mediates constriction to UTP. On the endothelium, $\mathrm{P} 2 \mathrm{Y}_{2}$ re- 
ceptors mediate vasodilatation to ATP and UTP via NO. 2MeSATP and ADP also mediate endothelium-dependent, NO-dependent relaxation, by a distinct $\mathrm{P} 2 \mathrm{Y}$ receptor.

\section{References}

ABBRACCHIO, M.P. \& BURNSTOCK, G. (1994). Purinoceptors: are there families of $\mathrm{P} 2 \mathrm{X}$ and $\mathrm{P} 2 \mathrm{Y}$ purinoceptors? Pharmacol. Ther., 64, $445-475$.

ALFIREVIC, Z. \& NEILSON, J.P. (1995). Doppler ultrasonography in high-risk pregnancies: systematic review with meta-analysis. Am. J. Obstet. Gynecol., 172, 1379-1387.

BUELL, G., LEWIS, C., COLLO, G., NORTH, R.A. \& SURPRENANT, A. (1996). An antagonist-insensitive P2X receptor expressed in epithelia and brain. EMBO J., 15, 55-62.

BURNSTOCK, G. \& KENNEDY, C. (1985). Is there a basis for distinguishing two types of $\mathrm{P}_{2}$-purinoceptor? Gen. Pharmacol., 16, $433-440$.

CHANG, K., HANAOKA, K., KUMADA, M. \& TAKUWA, Y. (1995). Molecular cloning and functional analysis of a novel $\mathrm{P}_{2}$ nucleotide receptor. J. Biol. Chem., 270, 26152-26158.

COLLO, G., NORTH, R.A., KAWASHIMA, E., MERLO-PICH, E., NEIDHART, S., SURPRENANT, A. \& BUELL, G. (1996). Cloning of $\mathrm{P} 2 \mathrm{X}_{5}$ and $\mathrm{P} 2 \mathrm{X}_{6}$ receptors, and the distribution and properties of an extended family of ATP-gated ion channels. J. Neurosci., 16, 2495-2507.

COMMUNI, D., PIROTTON, S., PARMENTIER, M. \& BOEYNAEMS, J.M. (1996a). Cloning and functional expression of a human uridine nucleotide receptor. J. Biol. Chem., 270, 30849-30852.

COMMUNI, D, PARMENTIER, M. \& BOEYNAEMS, J-M (1996b). Cloning, functional expression and tissue distribution of the human $\mathrm{P}_{2} \mathrm{Y}_{6}$ receptor. Biochem. Biophys. Res. Commun., 222 $303-308$.

CRACK, B.E., BEUKERS, M.W., MCKECHNIE, K.C.W., IJZERMAN, A.P. \& LEFF, P. (1994). Pharmacological analysis of ecto-ATPase inhibition: evidence for combined enzyme inhibition and receptor antagonism in P2X-purinoceptor ligands. Br. J. Pharmacol., 113, $1432-1438$

DIXON, C.J., COBBOLD, P.H. \& GREEN, A.K. (1995). Actions of ADP, but not ATP, on cytosolic free $\mathrm{Ca}^{2+}$ in single rat hepatocytes mimicked by 2-methylthioATP. Br. J. Pharmacol., 116, 19791984.

DOBRONYI, I., HUNG, K.-S., SATCHELL, D.G. \& MAGUIRE, M.H (1997). Evidence for a novel P2X purinoceptor in human placental chorionic surface arteries. Eur. J. Pharmacol., 320, $61-64$.

DUBYAK, G.R. \& EL-MOATASSIM, C. (1993). Signal transduction via P2-purinergic receptors for extracellular ATP and other nucleotides. Am. J. Physiol., 265, C577-C606.

EVANS, R.J. \& SURPRENANT, A. (1996). P2X receptors in autonomic and sensory neurons. Seminars Neurosci., 8, 217-223.

FEOLDE, E., VIGNE, P., BREITTMAYER, J.P. \& FRELIN, C. (1995). ATP, a partial agonist of atypical $\mathrm{P} 2 \mathrm{Y}$ purinoceptors in rat brain microvascular endothelial cells. Br. J. Pharmacol., 115, 11991203.

FREDHOLM, B.B., ABBRACCHIO, M.P., BURNSTOCK, G., DALY, J.W., HARDEN, K.T., JACOBSON, K.A., LEFF, P. \& WILLIAMS, M (1994). Nomenclature and classification of purinoceptors. Pharmacol. Rev., 46, $143-156$.

FRELIN, C., BREITTMAYER, J.P. \& VIGNE, P. (1993). ADP induces inositol phosphate-dependent intracellular $\mathrm{Ca}^{2+}$ mobilization in brain capillary endothelial cells. J. Biol. Chem., 268, 8787-8792.

GARCIA-GUZMAN, M., SOTO, F., GOMEZ-HERNANDEZ, J.M. LUND, P.E. \& STUMHER, W. (1997). Characterization of P2X receptor reveals pharmacological differences to the rat homologue. Mol. Phramacol., 51, $109-118$.

LEON, C., VIAL, C., CAZENAVE, J.-P. \& GACHET, C. (1995). Cloning and sequencing of a human endothelial $\mathrm{P}_{2} \mathrm{Y}_{1}$ purinoceptor. Direct submission of Z49205 to Genbank.
The authors are grateful to The Royal Society, London, U.K. (V.R and Tommy's Campaign, London, U.K. (S.B.) for their generous support.

NORTH, R.A. (1996). P2X purinoceptor plethora. Seminars Neurosci., 8, $187-194$

OLSSON, R.A. \& PEARSON, J.D. (1990). Cardiovascular purinoceptors. Physiol. Rev., 70, $761-845$.

PETIT, A. \& BELISLE, S. (1995). Stimulation of intracellular calcium concentration by adenosine triphosphate and uridine 5 '-triphosphate in human term placental cells: evidence for purinergic receptors. J. Clin. Endocrinol. Metab., 80, 1809-1815.

RALEVIC, V. \& BURNSTOCK, G. (1988). Actions mediated by P2purinoceptor subtypes in the isolated perfused mesenteric bed of the rat. Br. J. Pharmacol., 95, 49-56.

RALEVIC, V. \& BURNSTOCK, G. (1991). Effects of purines and pyrimidines on the rat mesenteric arterial bed. Circ. Res., 69, $1583-1590$

RALEVIC, V. \& BURNSTOCK, G. (1996). Discrimination by PPADS between endothelial P2Y- and P2U-purinoceptors in the rat isolated mesenteric arterial bed. Br. J. Pharmacol., 118, 428-434.

RALEVIC, V., BURRELL, S., KINGDOM, J. \& BURNSTOCK, G. (1996). Role of purine and pyrimidine nucleotides in the control of vascular tone in the human placenta. Drug Dev. Res., 37, 135.

RALEVIC, V.. MATHIE, R.T., ALEXANDER, B. \& BURNSTOCK, G. (1991). $\mathrm{N}^{\mathrm{G}}$-Nitro-L-arginine methyl ester attenuates vasodilator responses to acetylcholine but enhances those to sodium nitroprusside. J. Pharm. Pharmacol., 43, 871-874.

READ, M.A., BOURA, A.L.A. \& WALTERS, W.A.W. (1993). Vascular actions of purines in the foetal circulation of the human placenta. Br. J. Pharmacol., 110, 454-460.

REIMER, W.J. \& DIXON, S.J. (1992). Extracellular nucleotides elevate $\left[\mathrm{Ca}^{2+}\right]$ in rat osteoblastic cells by interaction with two receptor subtypes. Am. J. Physiol., 263, C1040-C1048.

SAIAG, B., MILON, D., ALlAIN, H., RAUlT, B. \& DRIESSCHE, V.D (1990). Constriction of the smooth muscle of rat tail and femoral arteries and dog saphenous vein is induced by uridine triphosphate via 'pyrimidinoceptors', and by adenosine triphosphate via P2X purinoceptors. Blood Vessels, 27, 352-364.

SAIAG, B., MILON, D., SHACOORI, V., ALLAIN, H., RAULT, B. \& VAN DEN DRIESSCHE, J. (1992). Newly evidenced pyrimidinoceptors and the P2X purinoceptors are present on the vascular smooth muscle and respectively mediate the UTP- and ATP-induced contractions of the dog maxilliary internal vein. Res. Commun. Chem. Pathol. Pharmacol., 76, 89-94.

SHIRASAKI, Y. \& SU, C. (1985). Endothelium removal augments vasodilation by sodium nitroprusside and sodium nitrite. Eur. J. Pharmacol., 114, 93-96.

VON KÜGELGEN, I., HÄUSSINGER, D. \& STARKE, K. (1987). Evidence for a vasoconstriction-mediating receptor for UTP, distinct from the P2 purinoceptor, in rabbit ear artery. NaunynSchmiedeberg's Arch. Pharmacol., 336, 556-560.

WEBB, T.E., FEOLDE, E., VIGNE, P., NEARY, J.T., RUNBERG, A., FRELIN, C. \& BARNARD, E.A. (1996). The P2Y purinoceptor in rat brain microvascular endothelial cells couple to inhibition of adenylate cyclase. Br. J. Pharmacol., 119, 1385-1392.

WINDSCHEIF, U., RALEVIC, V., BÄUMERT, H.G., MUTSCHLER, E., LAMBRECHT, G. \& BURNSTOCK, G. (1994). Vasoconstrictor and vasodilator responses to various agonists in the rat perfused mesenteric arterial bed: selective inhibition by PPADS of contractions mediated via P2X-purinoceptors. Br. J. Pharmacol., 113, $1015-1021$

ZIGANSHIN, A.U., HOYLE, C.H.V., LAMBRECHT, G., MUTSCHLER, E., BÄUMERT, H.G. \& BURNSTOCK, G. (1994). Selective antagonism by PPADS at P2X-purinoceptors in rabbit isolated blood vessels. Br. J. Pharmacol., 111, $923-929$.

(Received December 17, 1996 Revised April 18, 1997 Accepted April 21, 1997 